Article

\title{
Analysis of Photovoltaic Self-Consumption Systems
}

\author{
Carlos J. Sarasa-Maestro, Rodolfo Dufo-López and José L. Bernal-Agustín * \\ Department of Electrical Engineering, University of Zaragoza, Zaragoza 50018, Spain; \\ djcarlosjavier@gmail.com (C.J.S.-M.); rdufo@unizar.es (R.D.-L.) \\ * Correspondence: jlbernal@unizar.es; Tel.: +34-976-761-921
}

Academic Editors: Maurizio Sasso and Carlo Roselli

Received: 4 June 2016; Accepted: 22 August 2016; Published: 25 August 2016

\begin{abstract}
Components and installation prices could make the self-consumption of solar photovoltaic (PV) systems competitive. In this paper, we explore different self-consumption options, off-grid PV systems (with back-up generator and/or batteries), and grid-connected PV systems under net-metering policies. The calculation of the net present cost (NPC) reveals that the grid-connected PV-only case (for the net-metering scheme) is the most attractive from the technical and financial points of view, with a levelised cost of energy less than $0.1 € / \mathrm{kWh}$. Off-grid PV + Diesel + Batteries has a higher cost, around two or three times the grid-connected PV-only under net metering. Additionally, the off-grid PV + Diesel is less attractive from a financial point of view, which has a cost of around 10 times the PV-only under net metering. In addition, the values of life cycle $\mathrm{CO}_{2}$ emissions in each of the cases studied have been compared, and we have concluded that although the off-grid PV + Diesel + Batteries system presents lower $\mathrm{CO}_{2}$ emissions than the PV-only system, the existence of batteries does not allow one to affirm that the PV + Diesel + Batteries system is the best from an environmental point of view.
\end{abstract}

Keywords: photovoltaic tariffs; self-consumption; net metering; remuneration policies; grid parity

\section{Introduction}

Due to the many incentive programs that have been approved in the different countries where solar PV has been developed, PV generation has become one the most encouraged sources of energy generation [1]. In this context, there is a contrast between the various European PV markets. One of the main policy differences across the European countries is the possibility of consuming generated energy after it has been measured in the output meter (i.e., feed-in tariff (FiT)) [2]. When this option is enabled along with some kind of incentive scheme, the owner's cost per kilowatt-hour of energy consumed can be cheaper than that provided by the distributor network operator (DNO), as this system remunerates the owner for every kilowatt-hour generated. Most incentive schemes disappear over time [3] as their countries' markets grow. Therefore, the purpose of this paper is to start developing models to clarify the benefits associated with consuming all of the energy that a PV installation produces, even without financial support schemes such as FiT or a renewables obligation certificate (ROC). Assuming that grid parity is achieved, solar PV generation energy can be sold through the grid at a price similar to its purchase price. This scenario gives the energy provider multiple business opportunities, such as becoming a residential or commercial energy distributor. This scheme would create multiple miniature DNOs. For residential schemes, the risk is clearly defined and is comparable to that of a mortgage. Additionally, economic fluctuations and financial stability can vary by country [4]. Most of the developed countries in the world, including the United States, the United Kingdom, Italy, and Germany, are introducing self-consumption as their main solar PV development systems [5]. For example, the United States has promoted the market for distributed PV using net metering and support policies [6]. 
In the case of Spain, the decision to revoke the FiT [7] and the significant increase of electricity prices can turn self-consumption into an attractive concept due to its financial savings and stability $[8,9]$.

In terms of self-consumption, several authors have analysed PV systems, both economically and environmentally.

The effect of the demand profile's temporal resolution in the design and economics of PV self-consumption systems was studied in [10,11], which determined that good results can be reached at temporal resolutions of between 5 and $60 \mathrm{~min}$, although for the design of the storage system, it is advisable to use a relatively small temporal resolution (of at least $5 \mathrm{~min}$ ). These studies show the need to continue investigating this topic.

Other authors have focused on the use of batteries, with some affirming that the use of batteries can favour the increase of self-consumption installations [12]. Despite the high cost of these batteries, using them can be profitable if the price of electricity increases enough [13]; if the consumer pays higher prices during peak demand hours, batteries can result in significant savings on the consumer's electricity bill [14]. The researcher in [15] studied the effect that the application of demand-side management (DSM) programs, in combination with energy storage, had on the design of PV self-consumption systems, determining that no linear relation exists between electricity flows and storage capacity. Regarding DSM programs, the result obtained in [16] showed that using batteries is more effective than implementing DSM programs to promote self-consumption. However, despite the possible economic benefits, the negative environmental effects associated with the use of batteries are not often considered [17]. These negative environmental aspects, if they are considered and evaluated, could discourage the use of batteries in grid-connected systems.

Other studies about PV self-consumption systems have been conducted in various countries [18-22]. The results achieved show that, in many cases, self-consumption is economically viable, although its profitability depends on the regulatory policies that exist in each country. As the types of applicable rates determine the profitability of these installations [23], a proper normative regulation is needed to promote self-consumption [24].

Considering all of the above, this paper presents a study about self-consumption in Spain (both off-grid PV systems with batteries or diesel generators and grid-connected PV systems under net-metering policies), focusing on the economic and environmental aspects. The NPC is calculated in this economic study [25] for all cash flows during the system's lifetime (e.g., acquisition and installation costs, operation and maintenance costs, and replacement costs for components when their lifespan ends); the authors then converted to the initial system time by means of standard economic statistics (e.g., interest rate and inflation rate). In addition, the levelised cost of energy (LCOE) is obtained by dividing the NPC by the total load consumed during the system's lifetime. In this research's environmental study, the $\mathrm{CO}_{2}$ emissions for all components' life cycles are evaluated.

This paper focuses particularly on Spain's irradiance zone three (III), which includes the majority of Spain's mid-peninsular land. This zone includes Zaragoza, Madrid, most of Catalonia, Castilla Leon, Castilla La Mancha, Comunidad Valenciana, Extremadura, and Andalucía. The average household energy consumption is considered.

As a tool for the simulations and optimisations, the software iHOGA (improved Hybrid Optimisation by Genetic Algorithms, Dufo-López R., Zaragoza, Spain) [26] has been used. iHOGA is a simulation and optimisation software tool that optimises the hybrid renewable system, simulating the performance of the system on an hourly time-step basis throughout a whole year (which is supposed to be repeated until the end of the system's lifetime) or during the battery lifetime in the cases in which there is a battery in the system (when the battery's life ends, the old batteries are replaced with new ones, and the performance during the battery's lifetime is supposed to be repeated until the end of the system's lifetime). Systems with different combinations of components are tested to simulate their operation and to determine their performance during the system's lifetime. When systems comply with technical requirements, the NPC is calculated; across all the evaluated cases, the system lifetime averaged about 25 years (as is usual for PVs); the average interest rate was $4 \%$; and the general inflation 
rate was $2 \%$. Cash flows were analysed on a yearly basis. The main data input into iHOGA were system components, electricity demand, renewable resources, technical parameters, and economic parameters. More references about iHOGA can be found in previous papers $[27,28]$.

In this study, we assume that retail prices and net metering policies will not vary. The inclusion of changes to the retail rate design for distributed PV systems [29] and/or to the tariff policy [30] can affect the on-grid, PV-only system's results. The authors expect to address these research topics in future works.

This work is presented as follows: Self-consumption methods; Economic and energy data; Study cases; and Conclusions.

\section{Self-Consumption Methods}

The three self-consumption methods studied in this work are off-grid PV + Diesel systems, off-grid PV + Diesel + Batteries systems, and grid-connected PV-only systems under the net-metering policy [31]. The NPC and LCOE are used to determine the profitability of the different systems studied. The NPC or LCOE methodology allows one to calculate the required system and financial expenses necessary for each particular case [32]. However, one must consider that the LCOE is not the same as electricity prices; it is used as a proxy for the total price paid by consumers while considering as many realistic costs as possible.

Next, the three methods of self-consumption are briefly described.

\subsection{Off-Grid PV + Diesel System}

Figure 1 shows the basic elements for this system. In this case, the off-grid PV system uses a diesel generator as backup power supply when the PV panels do not provide the energy that the load demands. The lifespan of the generator has been considered, which mainly depends on the amount of hours it runs and its consumption of diesel.

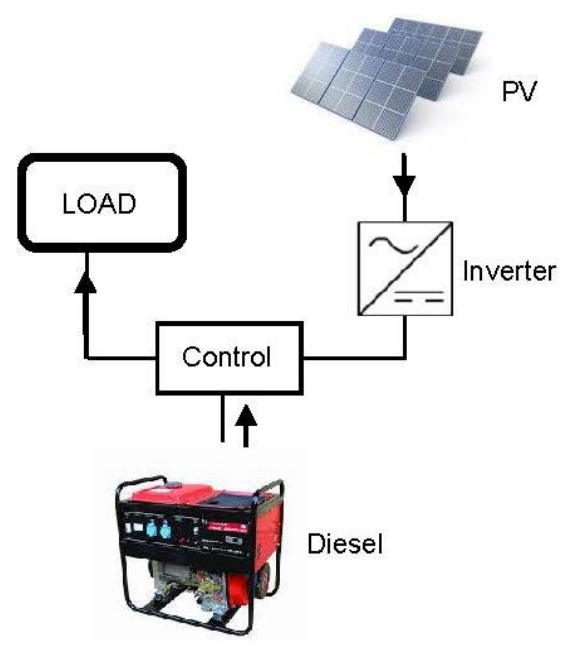

Figure 1. Off-grid PV + Diesel system.

\subsection{Off-Grid PV + Diesel + Batteries System}

Figure 2 shows the basic elements for this system. Storing the energy within batteries is advisable in off-grid PV systems, as there are periods without solar irradiation. Batteries store or supply energy depending the demand and generation. On the other hand, storing the energy within batteries increases the capital expenditure (CAPEX) and the operation and maintenance expenditure (OMEX), as the batteries need to be controlled and refilled. Additionally, after several years, their lifespans end, and they must be replaced. However, as diesel fuel consumption can be reduced, OMEX is reduced more prominently. 


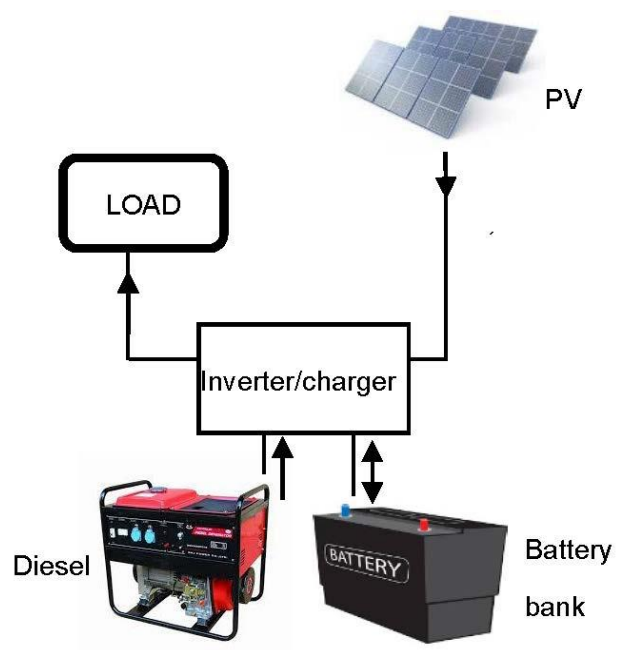

Figure 2. Off-grid PV + Diesel + Batteries system .

The models of the components are shown in [25]. The batteries' lifespan has to be considered within the finance scheme. The batteries considered in this paper are OPzS lead-acid with a cell voltage of $2 \mathrm{~V}$. The aging of the batteries is calculated using an advanced model created by Schiffer et al. in 2007 [33,34] that considers the capacity loss due to degradation of the active mass (taking into account the state of charge versus time, the current, the gassing, and the acid stratification) and capacity loss due to corrosion (considering the effect of temperature and voltage).

The lead-acid batteries stand out for their reliability and low cost [35]. In the future, it is possible that they will be replaced by lithium-ion batteries, which possess greater efficiency and longer lifetimes, but their higher cost implies that lead-acid batteries should continue to be the most used in renewable energy installations [36].

\subsection{Grid-Connected PV-Only System under Net-Metering Policy}

Figure 3 shows the basic elements for this system. Net metering allows the possibility that the consumer-generator uses the electricity produced directly. In addition, the excess energy can be injected into the grid and can use the grid like a storage system [8,37]. Effectively and financially, it is the best system, as no local physical storage system is needed, so a considerable reduction of CAPEX OMEX is expected.

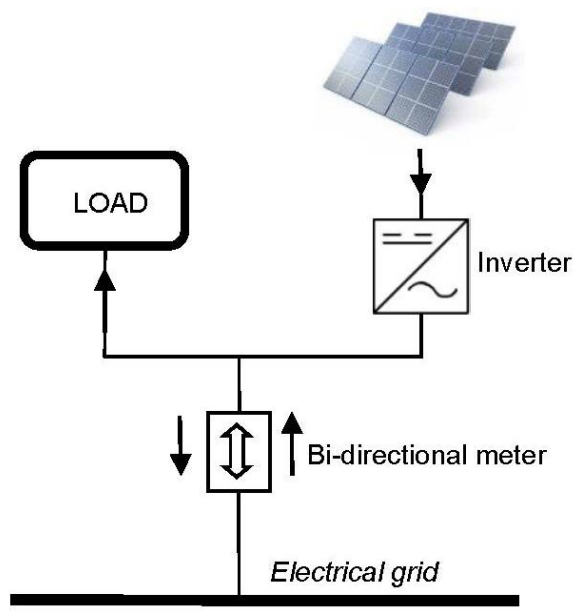

Figure 3. Grid-connected PV-only system under net-metering policy. 


\section{Energy and Economic Data}

Depending how accurately the system is calculated, the profitability of a system can be determined with high or low precision. A simple house with all the requirements for living in a modern society has been considered.

The total installed solar PV system cost includes the modules, inverter, support structure, electrical low-voltage circuits and protections, cables and structure anchor, engineering, mechanical installation, electrical installation, and value-added tax (VAT). The components can be weighted in order of price, which are the solar modules, inverter, structure, batteries, and manpower. Over the last five years, system costs have decreased by as much as $25 \%$ of their initial cost. This implies that it is possible to make the system competitive against other technologies and against the retail electricity price [32].

Next, we describe the data used in this study.

\subsection{Meteorological Data Sources}

There are many solar irradiance meteorological data sources available. Some of them are based on private weather stations. In this work, data from the Photovoltaic Geographical Information System (PVGIS) [38] have been used. The values for a place at zone III in Spain, with a slope of $15^{\circ}$ and oriented to the south, are shown in Table 1.

Table 1. Irradiance at zone III in Spain (Zaragoza).

\begin{tabular}{ccccc}
\hline Month & $\boldsymbol{E}_{\mathbf{d}}$ & $\boldsymbol{E}_{\mathbf{m}}$ & $\boldsymbol{H}_{\mathbf{d}}$ & $\boldsymbol{H}_{\mathbf{m}}$ \\
\hline January & 2.09 & 64.70 & 2.61 & 80.90 \\
February & 3.13 & 87.70 & 3.94 & 110.00 \\
March & 4.21 & 131.00 & 5.46 & 169.00 \\
April & 4.50 & 135.00 & 5.96 & 179.00 \\
May & 4.96 & 154.00 & 6.74 & 209.00 \\
June & 5.31 & 159.00 & 7.38 & 221.00 \\
July & 5.57 & 173.00 & 7.80 & 242.00 \\
August & 5.06 & 157.00 & 7.04 & 218.00 \\
September & 4.33 & 130.00 & 5.86 & 176.00 \\
October & 3.33 & 103.00 & 4.38 & 136.00 \\
November & 2.39 & 71.70 & 3.03 & 91.00 \\
December & 1.91 & 59.10 & 2.38 & 73.80 \\
\hline
\end{tabular}

$E_{\mathrm{d}}$ : Average daily electricity production per $\mathrm{kWp}$ of the PV system $(\mathrm{kWh} / \mathrm{kWp}) ; E_{\mathrm{m}}$ : Average monthly electricity production per $\mathrm{kWp}$ of the $\mathrm{PV}$ system $(\mathrm{kWh} / \mathrm{kWp}) ; H_{\mathrm{d}}$ : Average daily sum of global irradiation per square meter received by the modules of the given system $\left(\mathrm{kWh} / \mathrm{m}^{2}\right) ; H_{\mathrm{m}}$ : Average sum of global irradiation per square meter received by the modules of the given system $\left(\mathrm{kWh} / \mathrm{m}^{2}\right)$.

The reason why we are using a $15^{\circ}$ tilt angle is because it is a common inclination for a roof in that area of Spain. Nevertheless, the optimal angle for an installation connected to the grid would be $35^{\circ}$ tilt angle (maximising the electricity production of the whole year) and $60^{\circ}$ for an off-grid system (maximising the electricity production of the month with the lowest irradiation, usually December).

\subsection{PV Panels}

The PV panels comprise nearly 50\% of the budget (in grid-connected PV systems). The influence of Chinese manufacturers has reduced the global price of the system, but recently, anti-dumping policies have stopped this tendency [39]. Regulations imposed by the European Union say that it cannot be possible to assume lower prices for Chinese-manufactured solar panels [40].

The size of the installation directly affects the cost of the panels. In this case, we consider installations below $10 \mathrm{~kW}$. After reviewing the market, in 2016, the solar module price is around $0.55 € / \mathrm{Wp}$ for a $5 \mathrm{~kW}$ system. 


\subsection{Mounting Structures}

There are different prices depending on whether the structure is aluminium or hot galvanised steel. In the past, aluminium was a very expensive metal, making the hot galvanised mounting structures more competitive. Aluminium structures were priced at $0.34 € / \mathrm{Wp}$, but this price has decreased by $50 \%$ over the past few years because aluminium is more than 50\% cheaper in 2016 than it was in 2007 [41]. Typically, the mounting system on a rooftop installation is aluminium because it is lighter than the galvanised steel. With this in mind, we consider an aluminium structure in our budget.

\subsection{Inverters}

A solar inverter converts the DC output power from the solar panels into AC electricity that is synchronised with the AC frequency of the grid. For domestic applications, string inverters are the most used, and single-phase systems are the most common configuration on houses. For industrial or large-scale applications, a central inverter could be used. In this work, we consider a string inverter because of the size of the studied installations. Prices are around $0.1 € / \mathrm{Wn}$ for an industrial inverter and $0.24 € / W n$ for a $5 \mathrm{kWn}$ inverter, considering a European manufacturer. These prices are obtained through market research. The efficiency of the system could be improved using microinverters, but at the moment they are not very common in the market due to their high price.

\subsection{Energy Balance}

Sizing the system depends on the load consumption. Off-grid systems must be dimensioned following the worst-case scenario of consumption and also the worst-case scenario of generation (usually winter time). Furthermore, there are periods in which the energy produced by the system is greater than consumption and vice versa. However, grid-connected systems under net-metering policies should be dimensioned to produce approximately the same energy as the total energy consumed during the year.

Considering a solar PV generator installed in the roof of a house, the power consumption of a typical household located in Spain has been modelled.

The total consumption or energy demand per day is calculated using Equation (1).

$$
\text { Total consumption }\left(\frac{W h}{d a y}\right)=\sum(\text { Units.Power.Hours per day used })
$$

where Total consumption is the total electricity demand in the worst-case consumption scenario; Units is the number of units of the same item present in the house; Power is the maximum instant power consumed by the item; and Hours per day used is the number of hours per day of estimated use.

The house considered in this work has a power consumption of 10,000 Wh per day (a typical household load in Spain). The hourly consumption for the day (which is supposed to be repeated every day) is shown in Figure 4. The assumption that the behaviours of the tenants are constant all year has been considered; therefore, the hourly consumptions are the same, as some components and loads, like heaters, have been disregarded under the assumption that they are powered by gas. There is a demand peak at 21:00, usual in households in Spain. In Spain, it is common for dinner to start at 20:00, 21:00 or 22:00.

Demand growths have not been considered as it is a household load. The electrification of the house could be increased in the future (adding, for example, more automation for opening/closing window blinds, etc.); however, it has been considered that home appliances will consume less energy in the future, being more efficient, which can compensate for the increase in electrification.

The production generated over one year changes depending the amount of sunlight and the weather. Since the power production balance is not regular, the energy balance has to be regularised either with a storage system (batteries), backup diesel generator, or the AC grid (FiT or net-metering scheme). In this work, FiT has not been considered, as it tends to disappear. 


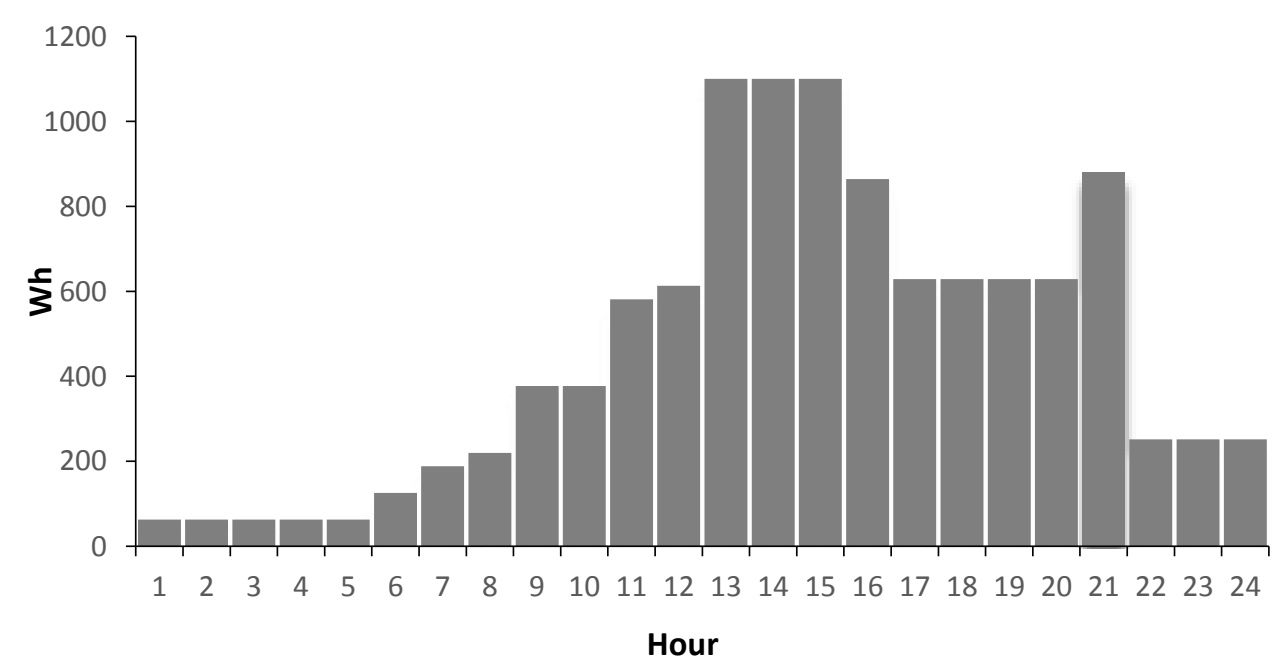

Figure 4. AC loads in a house throughout the year on an hourly basis.

\section{Study Cases}

\subsection{Off-Grid PV + Diesel System}

The following subsections describe the economic and environmental aspects of this system, and the final results are shown and analysed.

\subsubsection{Cost and $\mathrm{CO}_{2}$ Emissions of the PV + Diesel System}

To analyse the economic attractiveness of the PV + Diesel system, the costs of the solar PV panels, inverter controller (with maximum power point tracking (MPPT) to obtain the maximum power from the PV), the controller, and the diesel generator must be known. iHOGA software includes a section to introduce the financial parameters in case a loan is considered. In this work, loans to finance the PV system were not considered.

All of the prices introduced into iHOGA have been extracted from market research and are average reference prices (Table 2). In addition, life cycle $\mathrm{CO}_{2}$ emissions of the different components, including manufacturing, transport, mounting, disassembling, and recycling [42], are shown in Table 2.

Table 2. Prices of the used components.

\begin{tabular}{ccc}
\hline Component & Price per Watt (€/W) (Market Research) & Life Cycle $\mathbf{C O}_{\mathbf{2}}$ Emissions [42] \\
\hline PV Panel & 0.55 & $800 \mathrm{~kg} / \mathrm{kWp}$ \\
Mounting structure & 0.34 & Included in PV panel \\
Diesel Generator & 0.42 & $3.5 \mathrm{~kg} /$ litre of diesel fuel \\
Inverter with MPPT & 0.24 & Neglected \\
Controller & 0.31 & Neglected \\
\hline
\end{tabular}

The cost of the diesel fuel considered in this work is $1.3 € / \mathrm{L}$, with an expected annual fuel inflation rate of $5 \%$. The lifespan considered for the diesel generators is 10,000 running hours.

The cost of the rest of the system (electrical low voltage circuits and protections, electrical installation, mechanical installation, and engineering) has been considered as a fixed cost of $€ 300+2 \%$ of the total cost of the components. DC bus voltage is $48 \mathrm{~V}$ and AC bus is $230 \mathrm{~V}$. PV panels of $280 \mathrm{Wp}$ and $24 \mathrm{~V}$ of nominal voltage have been considered, and two panels must be connected serially in order to obtain $48 \mathrm{~V}$ in the DC bus. The number of strings of PV panels in parallel can vary from 0 to 12 . Inverters considered range from 0 to $1.8 \mathrm{~kW}$ in $0.6 \mathrm{~kW}$ steps. The diesel 
generators considered are of $0,1.9$, and $3 \mathrm{kVA}$. The software will consider the different combinations of components, simulating all of them and obtaining the economic results for each combination.

\subsubsection{Analysis and Simulation}

In this work, the objective is to minimise LCOE [32] or the NPC. The software allows other objectives for optimisation, but in this case, the main objective is to minimise LCOE (i.e., minimise NPC). For this purpose, the results given by iHOGA have been sorted from top (the best or lowest NPC) to bottom (the worst or highest NPC). The results are shown in Table 3.

Table 3. Main results of the best combinations given by iHOGA solar PV + Diesel.

\begin{tabular}{|c|c|c|c|c|c|c|}
\hline Project & $\operatorname{NPC}(€)$ & $\begin{array}{l}\text { PV Power } \\
\quad(\mathrm{Wp})\end{array}$ & $\begin{array}{l}\text { Diesel-Generator } \\
\text { Power (VA) }\end{array}$ & $\begin{array}{c}\text { Inverter } \\
\text { Power (W) }\end{array}$ & $\begin{array}{c}\text { Life Cycle } \mathrm{CO}_{2} \\
\text { Emissions } \\
\text { (kg/year) }\end{array}$ & $\begin{array}{r}\mathrm{LCOE}^{*} \\
(€ / \mathbf{k W h})\end{array}$ \\
\hline 1 & $84,546.67$ & 5040 & 1900 & 1800 & 5502.58 & 0.927 \\
\hline 2 & $84,966.16$ & 4480 & 1900 & 1800 & 5547.78 & 0.931 \\
\hline 3 & $86,084.03$ & 3920 & 1900 & 1800 & 5632.78 & 0.943 \\
\hline 4 & $87,056.42$ & 3360 & 1900 & 1800 & 5717.98 & 0.954 \\
\hline 5 & $89,193.91$ & 2800 & 1900 & 1800 & 5882.74 & 0.977 \\
\hline 6 & $94,039.39$ & 2240 & 1900 & 1800 & 6239.74 & 1.031 \\
\hline 7 & $106,169.12$ & 1680 & 1900 & 1800 & 7108.84 & 1.163 \\
\hline 8 & $120,735.10$ & 5040 & 3000 & 1800 & 8494.37 & 1.323 \\
\hline 9 & $121,567.34$ & 4480 & 3000 & 1800 & 8574.74 & 1.332 \\
\hline 10 & $123,412.16$ & 3920 & 3000 & 1800 & 8717.81 & 1.352 \\
\hline
\end{tabular}

As mentioned previously, the purpose of this simulation is to find out which is the best configuration in financial terms; therefore, Project 1 (Table 3$)$, which has the best NPC $(€ 84,546.67)$, will be analysed in detail. Project 1 is composed of $18 \mathrm{PV}$ panels of $280 \mathrm{Wp}$ (connected in strings of two panels in serial, and nine strings in parallel), with a peak power of $5.04 \mathrm{kWp}$. The diesel generator has $1.9 \mathrm{kVA}$ of power, and the inverter has $1.8 \mathrm{~kW}$ of power. The inverter size is adequate to supply the maximum load. The PV generator's maximum power is much higher than the rated power of the inverter (2.8 times). This means that a part of the energy produced by the PV generator will not be used. In spite of this, it is the optimal system. This is due to the fact that a smaller number of panels would imply an increased annual consumption of diesel, giving rise to a high NPC. In addition, Table 3 shows the relationship between the NPC and the lifecycle $\mathrm{CO}_{2}$ emissions, which are calculated with consideration of the lifecycle emissions (manufacturing, transport, mounting, disassembling, and recycling the components), as shown in [42].

The results show that the most rentable system (Project 1 ) is also the most beneficial for the environment, as it is the option with the fewest $\mathrm{CO}_{2}$ emissions.

\subsubsection{Financial Evaluation}

The financial results and cash flow provided by iHOGA for the best combination of components (Project 1) is shown graphically in Figure 2, which provides information about how to structure the cash flow during the life cycle of the installation. The cash flow in the last year is dramatically smaller than the previous years because it is assumed that at the end of the system's lifetime the remaining value of the components of the system is obtained by selling them. For example, if at the end of the system's lifetime (year 25) the diesel generator has performed at $50 \%$ of its lifetime, then it is expected to obtain cash flow by selling it at $50 \%$ of its acquisition cost.

Figure 5 shows that there are some years in which the cash resources need to be higher than others. Years 11 and 21 are the most expensive, as some components, like the inverter, need to be 
replaced at this time. On the other hand, the diesel generator has to be replaced every two years. Thus, every two years, the price of the generator is added into the expected cash flow.

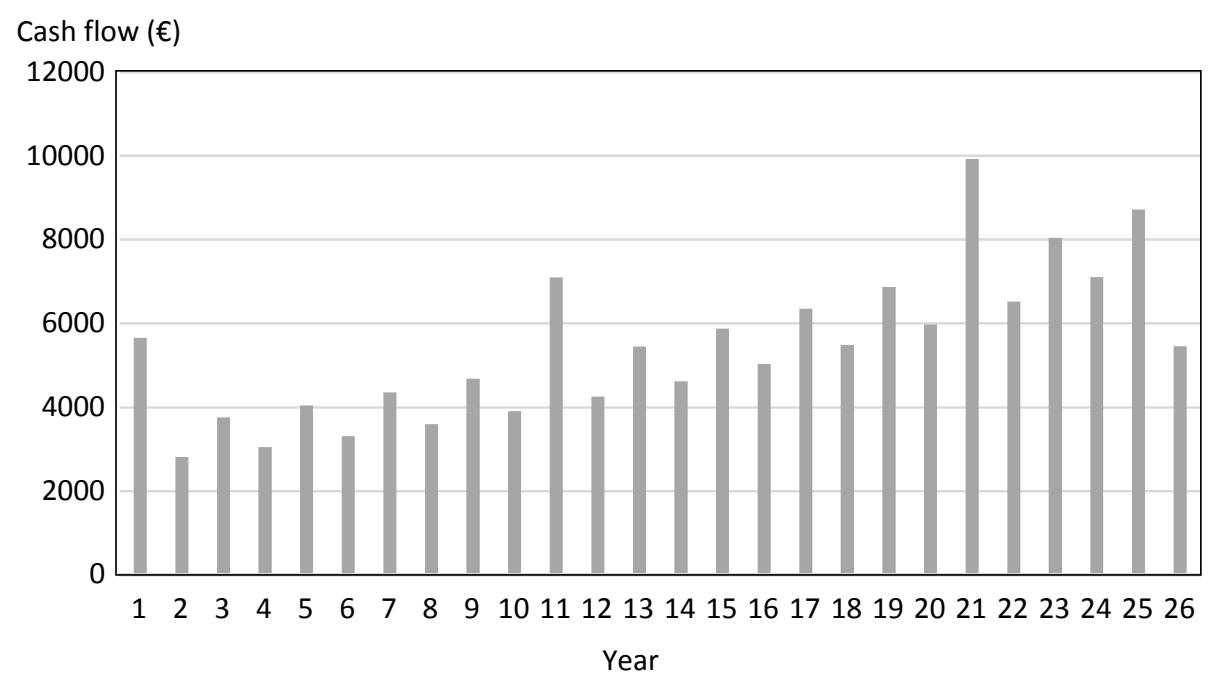

Figure 5. Cash flow of the solar PV system with a diesel generator.

\subsubsection{Sensitivity Analysis}

A sensitivity analysis has been performed considering the variation in PV panel costs (comparing the base case of $0.55 € / \mathrm{Wp}$ and a case to a higher PV cost of $1 € / \mathrm{Wp}$ ) and the variation of the annual inflation of diesel fuel (comparing the base case of $5 \%$ to $3 \%, 1 \%$, and $-1 \%$ ).

Figure 6 shows the main results (PV size, NPC, and life cycle $\mathrm{CO}_{2}$ emissions) of the optimal solution found for the case of PV costs of $0.55 € / \mathrm{Wp}$, with a varying annual fuel inflation rate. All of the optimal solutions have the same configuration: PV of $5.04 \mathrm{kWp}$, diesel generator of $1.9 \mathrm{kVA}$, and inverter of $1.8 \mathrm{~kW}$. Since all of them have the same fuel consumption, emissions are the same. However, the NPC falls as the annual fuel inflation price decreases.

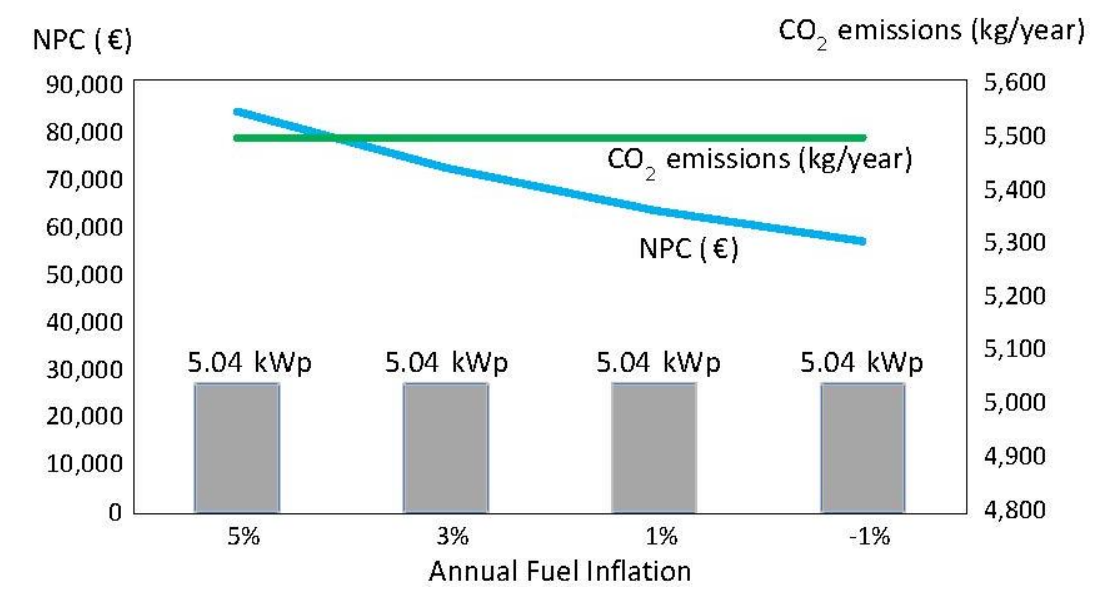

Figure 6. PV + Diesel systems. Optimal solutions include cases with a PV cost of $0.55 € / \mathrm{Wp}$.

Figure 7 shows the main results of the optimal solution found for the case of a PV cost of $1 € / W p$, with varying annual fuel inflation rates. The optimal solutions for $5 \%$ and $3 \%$ have same configuration as the ones in Figure 6. However, the optimal solutions for $1 \%$ and $-1 \%$ include a lower PV generator (and therefore higher fuel consumption and emissions); the optimal solution is as follows: PV of $4.48 \mathrm{kWp}$, diesel generator of $1.9 \mathrm{kVA}$, and inverter of $1.8 \mathrm{~kW}$. Comparing Figure 6 with Figure 7 , 
the NPC of the cases of PV $1 € / \mathrm{Wp}$ are a little higher than the cases of PV $0.55 € / \mathrm{Wp}$. There is a small difference in NPCs between Figures 7 and 8 because the main change in the NPC is due to fuel consumption, while the PV generator cost is a minor factor of the NPC. Thus, the variable which most affects the NPC of PV + Diesel is the annual fuel price inflation.

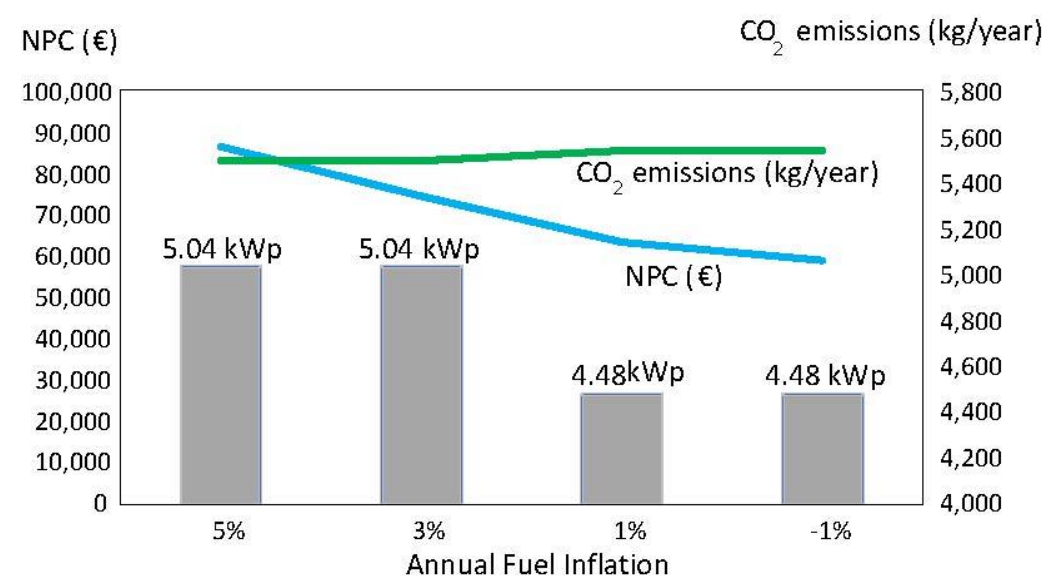

Figure 7. PV + Diesel systems. Optimal solutions include cases with a PV cost of $1 € / W p$.

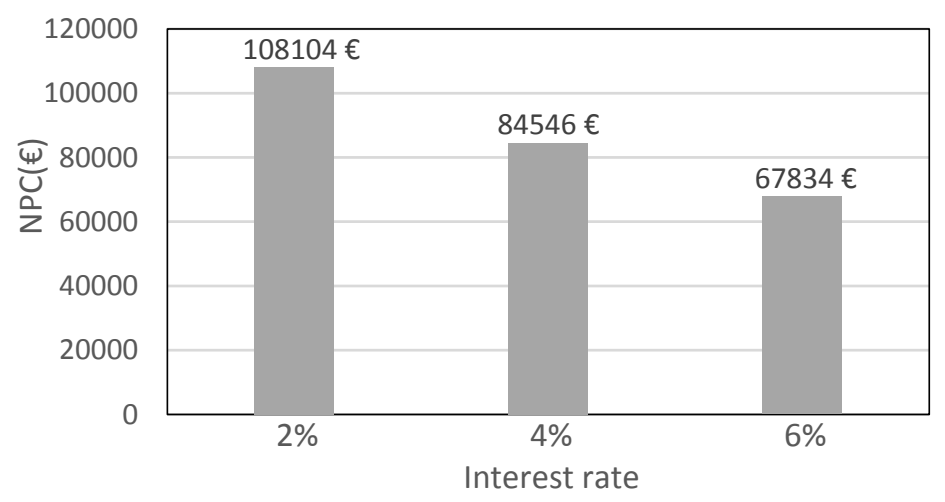

Figure 8. PV + Diesel systems. Effect on the NPC of the interest rate.

Another sensitivity analysis has been performed that takes the variation in the interest rate into consideration. The base case uses a $4 \%$ interest rate, and two other cases- $2 \%$ and $6 \%$-have been analysed. In all cases, the optimal system is the same, but the NPC is highly affected, as shown in Figure 8.

Finally the effect of the loan has been evaluated. The base case uses no loan. Another case has been optimised that considers a loan of $80 \%$ of the initial acquisition cost of the system paid over 10 years with an interest rate of $7 \%$. The optimal system is the same. However, the NPC is now of $€ 85,247$. There is no high increment in NPC due to the loan, as the NPC is poorly affected by the initial acquisition cost of the system.

\subsection{Off-Grid PV + Diesel + Batteries System}

In this case, the batteries can supply the load when there is not enough generation from the PV panels. The cases of Diesel + Batteries (without PV) and PV + Batteries (without diesel) are also considered. In the cases of PV + Batteries (without diesel), dimensioning the batteries depends on the required number of days of autonomy. In these cases, a minimum of four days of autonomy has been considered. The batteries considered are OPzS lead-acid, with a range of $180 \mathrm{Ah}$ to $2800 \mathrm{Ah}$ of nominal capacity, nominal cell voltage of $2 \mathrm{~V}, 1254$ full cycles to failure, and a $20 \%$ minimum-allowed state of charge (SOC). As the DC bus is $48 \mathrm{~V}, 24$ batteries must be connected serially. The sizes of the 
$\mathrm{PV}$, diesel and inverter/charger taken into account are same as in the previous section. The number of battery strings in parallel considered are from 0 to 4 . In this case, the inverter/chargers is considered, which is an inverter with a battery charger and control unit, including the battery controller (to prevent overcharge and over-discharge) and battery charger (so that the diesel can charge the battery bank). The control strategy is "load following" so that when there is inadequate power from the PV, the battery will supply the load; the diesel generator will only run to supply the load when the batteries reach a low SOC $(20 \%)$. The battery bank is charged by the PV, but the inverter/charger forces the diesel to periodically (every fourteen days or after eight nominal charge throughputs) fully charge the battery bank.

\subsubsection{Cost and Emissions of the System (PV + Diesel + Batteries)}

The costs of previous sections (Table 2 ) are considered. The considered battery cost is $352 € / \mathrm{kWh}$ of nominal capacity, and the inverter/charger has a cost of $1.35 € / \mathrm{W}$ (these are based on market research and are average reference prices). In order to calculate the cost to replace the batteries, we assume a reduction in their acquisition cost by $2 \%$ annually, with a maximum reduction of $60 \%$. Again, no loans have been considered to finance the PV system. Life cycle $\mathrm{CO}_{2}$ emissions of the batteries are $55 \mathrm{~kg} / \mathrm{kWh}$ [42], while the emissions of the electronic components are negligible.

\subsubsection{Analysis and Simulation}

The objective is to minimise the LCOE (or the NPC). The results are sorted from top (the best or lowest NPC) to bottom (the worst or highest NPC) (Table 4). The best configuration, in financial terms, is Project 1 , which is the one with the best NPC $(€ 20,039.73)$.

Table 4. Main results of the best combinations given by iHOGA solar PV + Diesel + Batteries.

\begin{tabular}{|c|c|c|c|c|c|c|c|}
\hline Project & $\operatorname{NPC}(€)$ & $\begin{array}{l}\text { PV Power } \\
\text { (Wp) }\end{array}$ & $\begin{array}{l}\text { Diesel-Generator } \\
\text { Power (VA) }\end{array}$ & $\begin{array}{c}\text { Battery } \\
\text { Bank (Wh) }\end{array}$ & $\begin{array}{c}\text { Energy } \\
\text { Supplied by } \\
\text { Diesel }(\%)\end{array}$ & $\begin{array}{c}\text { Life Cycle } \mathrm{CO}_{2} \\
\text { Emissions } \\
(\mathrm{kg} / \text { year })\end{array}$ & $\begin{array}{c}\mathrm{LCOE} \\
(€ / \mathrm{kWh})\end{array}$ \\
\hline 2 & $22,274.81$ & 4480 & 1900 & 8640 & 1.07 & 288.27 & 0.244 \\
\hline 3 & $22,729.77$ & 5040 & 1900 & 8640 & 1.04 & 305.09 & 0.249 \\
\hline 4 & $22,915.09$ & 3920 & 3000 & 8640 & 2.27 & 353.31 & 0.251 \\
\hline 7 & $23,448.29$ & 3920 & 1900 & 18,720 & 0.03 & 289.23 & 0.257 \\
\hline 8 & $23,714.68$ & 3920 & 3000 & 18,720 & 0.05 & 290.28 & 0.260 \\
\hline 9 & $24,205.69$ & 4480 & 1900 & 18,720 & 0.01 & 314.26 & 0.265 \\
\hline 10 & $24,230.97$ & 3920 & 1900 & 12,960 & 0.22 & 249.2 & 0.266 \\
\hline
\end{tabular}

Project 1 is comprised of 14 panels connected serially in seven strings of two, with a peak power of $3.92 \mathrm{kWp}$. The diesel generator has $1.9 \mathrm{kVA}$ of power, and the inverter/charger is $1.8 \mathrm{~kW}$. In this case, there is a unique string of 24 batteries of $180 \mathrm{Ah}$ in series, providing a total capacity of $8.64 \mathrm{kWh}$. The PV generator/inverter power ratio is 2.18. Again, this difference is because with a lower PV generator, the annual consumption of diesel would be more expensive due to the amount of hours needed to supply the power demanded.

Comparing for example Projects 1 and 3, it can be seen that $\mathrm{CO}_{2}$ emissions are higher for Project 3 than for Project 1, however, PV power is higher in Project 3 and therefore the energy supplied by diesel (and therefore the fuel consumption) is lower. This is because the $\mathrm{CO}_{2}$ emissions (kg/year) have been calculated to include all the emissions in the lifetime of the system, divided by 25 years. It considers not only the emissions due to the diesel fuel, but also the emissions due to the manufacturing, transport, mounting, disassembling, and recycling of the components of the system (PV, diesel generator and battery bank). A higher PV generator means more $\mathrm{CO}_{2}$ emissions due to the manufacturing, transport, mounting, disassembling, and recycling of the PV generator. 


\subsubsection{Sensitivity Analysis}

A sensitivity analysis has been performed considering the variation in PV panel cost (comparing the base case of $0.55 € / \mathrm{Wp}$ to a case with a higher PV cost of $1 € / \mathrm{Wp}$ ), the variation of battery cost (comparing the base case of $352 € / \mathrm{kWh}$ to other cases of $250 € / \mathrm{kWh}$ and $450 € / \mathrm{kWh}$ ), and the variation of the annual inflation of diesel fuel (comparing the base case of $5 \%$ to $3 \%, 1 \%$, and $-1 \%$ ).

Figure 9 shows the NPC of the optimal solutions found for each combination of PV price, battery price, and annual fuel inflation. All of the optimal solutions are the same configuration and therefore same emissions: PV of $3.92 \mathrm{kWp}$, diesel of $1.9 \mathrm{kVA}$, inverter/charger of $1.8 \mathrm{~kW}$, and battery bank of $8.64 \mathrm{kWh}$. NPC varies from around $€ 19,000$ to $€ 26,000$. In this case, the annual fuel inflation did not have a great influence on NPC. However, the price of PV panels and batteries did have an important influence.

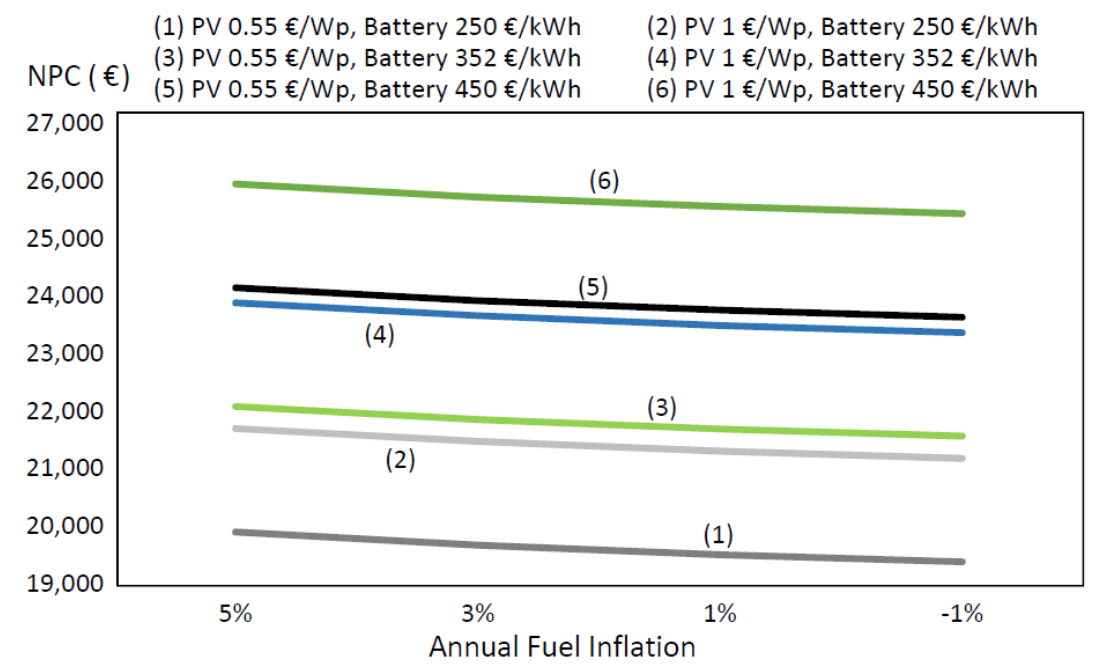

Figure 9. Sensitivity analysis, PV + Diesel + Battery systems. NPC of the optimal solutions.

Another sensitivity analysis has been performed with consideration for the variation of the interest rate. The base case uses a $4 \%$ interest rate, and two other cases have been analysed: $2 \%$ and $6 \%$. In all cases, the optimal system is the same. However, the NPC is affected, but less than in the case of PV + Diesel, as shown in Figure 10.

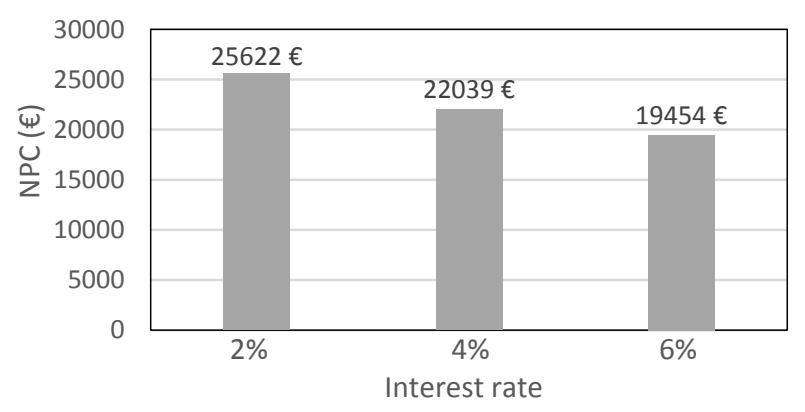

Figure 10. PV + Diesel + Battery systems. Effect on the NPC of the interest rate.

Finally the effect of the loan has been evaluated. The base case uses no loan. Another case has been optimised that considers a loan of $80 \%$ of the initial acquisition cost of the system paid over 10 years with an interest rate of $7 \%$. The optimal system is the same, but the NPC is now of $€ 27,386$. There is a notable increment in NPC due to the loan, as NPC is affected by the initial acquisition cost of the system. 


\subsection{Grid-Connected PV-Only System under Net-Metering Policy}

In this case, the house is grid connected under a net-metering scheme. In this work, the modality of net metering considered is "net metering, one-year rolling credit" [8], as it is the most widely used scheme. In this net-metering scheme, all of the energy injected in the electrical grid can be consumed for free throughout year, but if the energy injected is higher than the energy consumed from the grid, there is no buyback possibility. Injecting energy into the grid does not imply adding any technical components or cost (for example, in the United States a net metering scheme is used in most of the states, without extra costs), though there could be an administrative cost depending on the country or region in which this scheme is developed. The PV panels and inverters in Section 4.1, Table 2, have been considered. The purchasing price of the energy is 15 euro cents per $\mathrm{kWh}$ for the base case, with an expected inflation of 3\% annually. Again, no loans were considered to finance the PV system, and all of the prices introduced into iHOGA are the same as in the previous sections. Life cycle $\mathrm{CO}_{2}$ emissions of the energy consumed from the $\mathrm{AC}$ grid depend on the electricity mix of the grid in the given country. A value of $0.4 \mathrm{~kg} / \mathrm{kWh}$ was considered [42], which will be applied to the amount of energy consumed from the AC grid that was not previously injected in the grid (i.e., applied to the difference between the energy consumed from the AC grid and the energy injected into the AC grid).

\subsubsection{Analysis and Simulation}

The results of the optimisation (minimisation of NPC or LCOE) have been classified from top (the best NPC) to bottom (the worst NPC; Table 5). The last one (Project 10) is a case without a PV system, (i.e., all of the energy demanded by the load is bought from the AC grid).

Table 5. Project results given by iHOGA. Solar PV on net-metering scheme.

\begin{tabular}{cccccc}
\hline Project & NPC $(\boldsymbol{\epsilon})$ & PV Power $(\mathbf{W p})$ & Inverter Power $(\mathbf{W})$ & $\begin{array}{c}\text { Life Cycle CO } \mathbf{C}_{\mathbf{2}} \\
\text { Emissions (kg/year) }\end{array}$ & LCOE (€/kWh) \\
\hline 1 & 6992.04 & 2240 & 1800 & 536.35 & 0.077 \\
2 & 7283.79 & 2800 & 1800 & 528.34 & 0.080 \\
3 & 7992.29 & 3360 & 1800 & 532.1 & 0.088 \\
4 & 8700.79 & 3920 & 1800 & 540.31 & 0.095 \\
5 & 9054.32 & 1680 & 1800 & 585.91 & 0.099 \\
6 & 9409.29 & 4480 & 1800 & 551.05 & 0.103 \\
7 & $10,117.78$ & 5040 & 1800 & 563.49 & 0.111 \\
8 & $11,235.35$ & 1120 & 1800 & 778.75 & 0.123 \\
9 & $13,534.41$ & 560 & 1800 & 1113.97 & 0.148 \\
10 & $15,057.88$ & 0 & 0 & 1459.99 & 0.165 \\
\hline
\end{tabular}

The best configuration, in financial terms, is Project 1, which had the best NPC (€6992.04), composed of eight panels (two connected serially and four strings in parallel), with a peak power of $2.24 \mathrm{kWp}$. The inverter has $1.8 \mathrm{~kW}$ of nominal power. The solar PV system cannot cover the whole load demanded by the house, so the rest of the energy demanded has to be supplied by the grid. Project 1 is one of the most beneficial options for the environment.

Comparing Projects 2 and 4, we can see that increasing the PV power does not always imply decrement of the $\mathrm{CO}_{2}$ emissions. As the PV generator power increases, the energy supplied from the AC grid decreases, decreasing the $\mathrm{CO}_{2}$ emissions associated to that energy (a value of $0.4 \mathrm{~kg} / \mathrm{kWh}$ has been considered). The emissions from PV (the manufacturing, transport, mounting, disassembling, and recycling of the PV generator) are lower than $0.4 \mathrm{~kg} / \mathrm{kWh}$. However, as PV generation increases, under net metering it can happen that the energy generated by the PV during the year is higher than the energy consumed by the load, then the excess energy injected into the grid will not be returned. This is why Project 4 has more emissions than 2. Project 4 uses a $3920 \mathrm{Wp}$ PV generator, generating around $7000 \mathrm{kWh} /$ year. If the load consumes $3650 \mathrm{kWh} /$ year, then there are $7000-3650=3350 \mathrm{kWh} /$ year injected into the grid that are not used later by the load. 


\subsubsection{Sensitivity Analysis}

A sensitivity analysis has been performed considering the variation in PV panel cost (comparing the base case of $0.55 € / \mathrm{Wp}$ to a case with a higher PV cost of $1 € / \mathrm{Wp}$ ), the variation of the purchased electricity price (comparing the base case of $0.15 € / \mathrm{kWh}$ to 0.1 and $0.2 € / \mathrm{kWh}$ ), and the variation of the inflation of the purchased electricity price (comparing the base case of $3 \%$ to $1 \%$ and $5 \%$ ).

Figure 11 shows the NPC of the optimal solutions found for each combination for PV price, electricity price, and annual electricity price inflation. All of the optimal solutions have the same configuration and therefore the same life cycle emissions (PV of $2.24 \mathrm{kWp}$, inverter of $1.8 \mathrm{~kW}$, with $536 \mathrm{kgCO}_{2} /$ year), except for the cases of $0.55 € / \mathrm{Wp}, 0.2 € / \mathrm{kWh}, 3 \%$ and $5 \%$ and the case of $1 € / \mathrm{Wp}$, $0.2 € / \mathrm{kWh}, 5 \%$, for which optimal solutions are a PV of $2.8 \mathrm{kWp}$ and an inverter of $1.8 \mathrm{~kW}$ (with life cycle emissions of $528 \mathrm{kgCO}_{2}$ /year). Electricity price inflation did not have a great influence on NPC. However, the price of PV panels did have a great influence, and the price of electricity had a relatively low influence (as in the optimal systems, the amount of the energy injected into the AC grid is a little lower than the energy consumed from the AC grid).

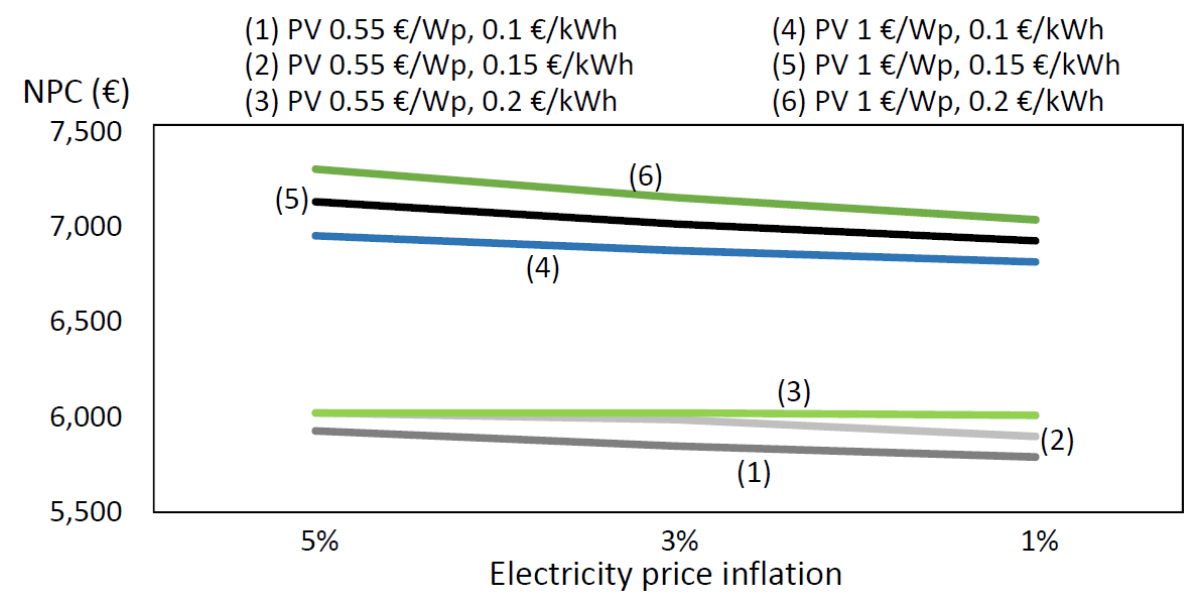

Figure 11. Sensitivity analysis, PV-only systems under net-metering scheme. NPC of the optimal solutions.

Another sensitivity analysis has been performed with consideration for the variation of the interest rate. The base case uses a $4 \%$ interest rate, and the other two cases have used rates of $2 \%$ and $6 \%$. In all cases, the optimal system is the same. However, the NPC is barely affected, as shown in Figure 12.

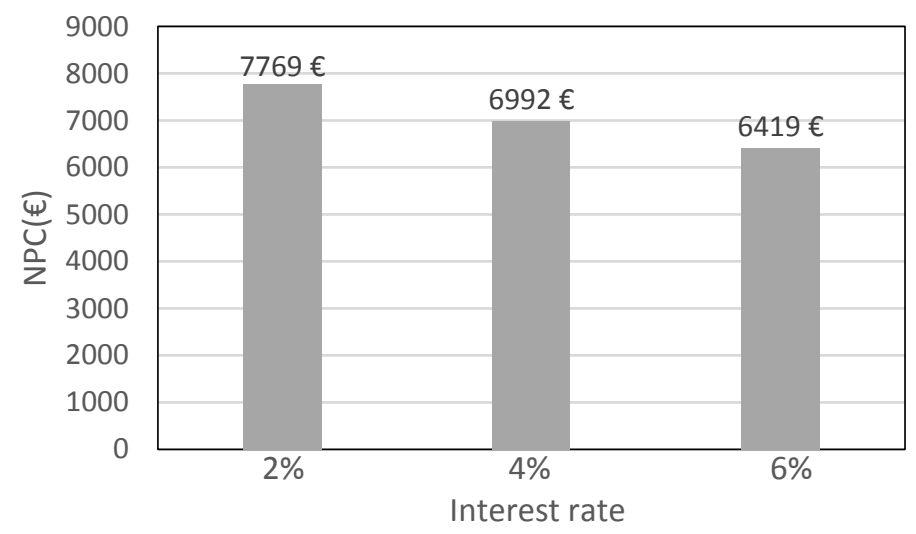

Figure 12. PV-only systems. Effect on the NPC of the interest rate. 
Finally the effect of the loan has been evaluated. The base case uses no loan, while another case has been optimised considering a loan of $80 \%$ of the initial acquisition cost of the system with an interest rate of $7 \%$ over 10 years. The optimal system is the same. However, the NPC is now of $€ 7381$. There is a low increment in NPC due to the loan, as the NPC is poorly affected by the initial acquisition cost of the system.

\section{Comparison of the Optimal Results of the Base Cases}

Focussing on only the financial point of view, the NPC of the optimal combinations of each case are shown in Figure 13.

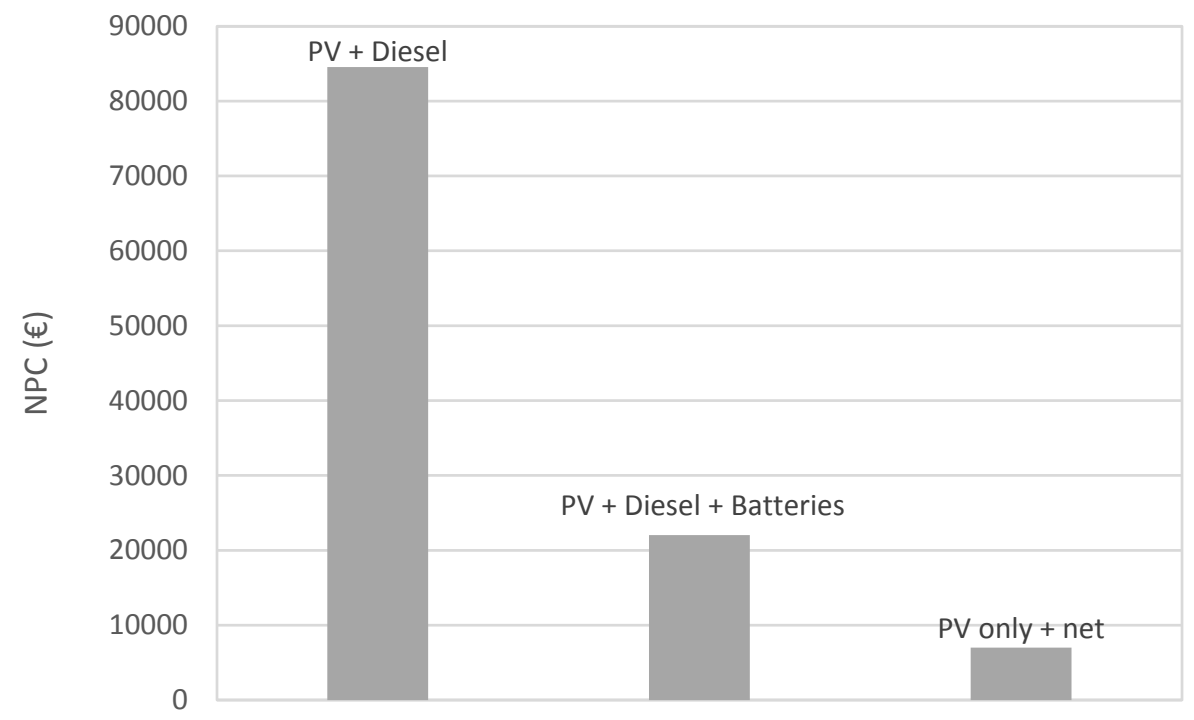

Figure 13. NPC of the different schemes. All cases represented.

$\mathrm{PV}+$ Diesel is the least attractive case financially compared to the other cases, while on-grid PV-only under net metering is the best configuration.

Considering environmental aspects (life cycle $\mathrm{CO}_{2}$ emissions), Figure 14 shows that $\mathrm{PV}+$ Diesel + Batteries emits the least amount of $\mathrm{CO}_{2}$.

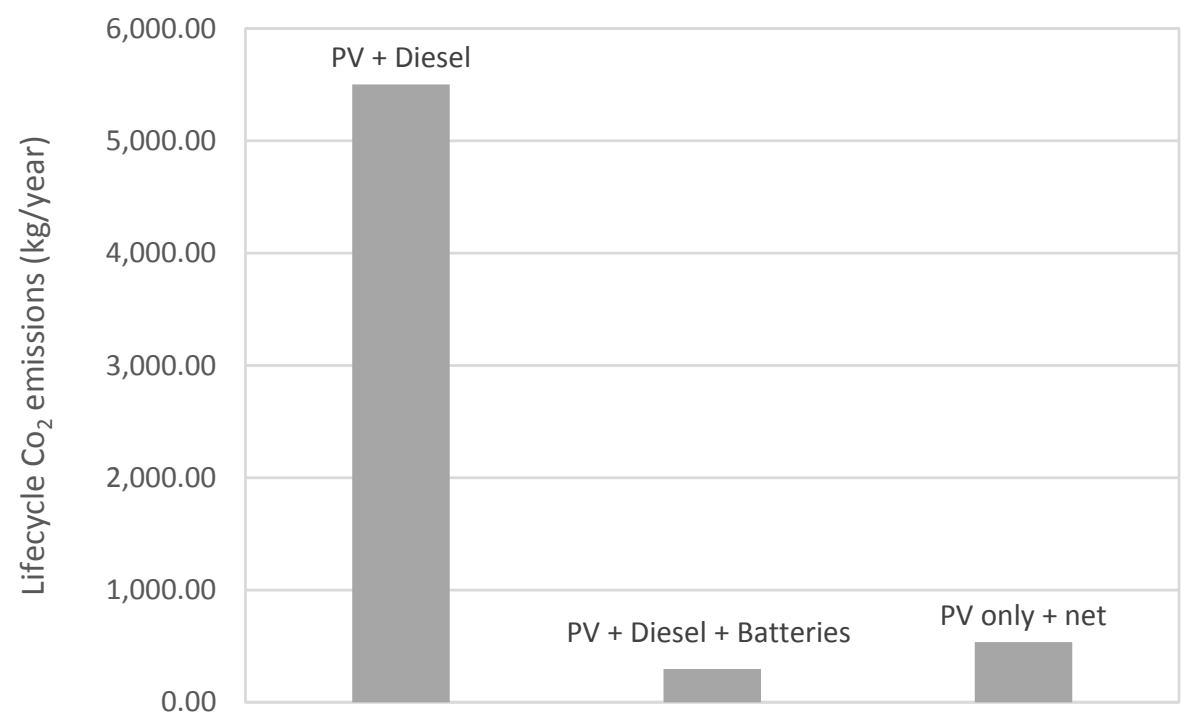

Figure 14. Lifecycle $\mathrm{CO}_{2}$ emissions of the different schemes. All the cases represented. 
In this study, we have taken into account the $\mathrm{CO}_{2}$ emissions caused by the production, transportation and recycling of the batteries, but all the negative environmental impacts of the use of batteries has not been evaluated and considered. This topic has been widely studied by other authors $[17,43,44]$, and it is possible to affirm, on the basis of these works, that the existence of batteries in the PV + Diesel + Batteries system still makes the PV-only system the best for the environment.

Table 6 shows a summary of the optimal solutions obtained in each case study.

Table 6. Summary of the optimal project results obtained by iHOGA.

\begin{tabular}{|c|c|c|c|c|c|c|c|c|}
\hline Case Study & $\begin{array}{l}\text { Off-Grid/ } \\
\text { Net-Metering }\end{array}$ & \multicolumn{4}{|c|}{ Optimal Configuration } & $\operatorname{NPC}(€)$ & $\begin{array}{l}\text { LCOE } \\
(€ / \mathbf{k W h})\end{array}$ & $\begin{array}{c}\text { Life Cycle } \mathrm{CO}_{2} \\
\text { Emissions } \\
\text { (kg/year) }\end{array}$ \\
\hline PV + Diesel & Off-grid & 5.04 & 1.8 & 1.9 & $\mathrm{~N} / \mathrm{A}$ & 84,546 & 0.927 & 5502 \\
\hline $\begin{array}{c}\text { PV + Diesel + } \\
\text { Batteries }\end{array}$ & Off-grid & 3.92 & 1.8 & 1.9 & 8.64 & 22,039 & 0.242 & 297 \\
\hline
\end{tabular}

\section{Conclusions}

This paper presented the optimisation of three different kinds of photovoltaic-based systems to supply the electrical load of a typical household $(10 \mathrm{kWh} /$ day $)$. The systems considered were: (1) off-grid PV + Diesel; (2) off-grid PV + Diesel + Batteries; and (3) on-grid PV systems under net metering with one-year rolling credit modality. The results show that the PV system under the net-metering scheme is the one with lowest NPC and LCOE, around two or three times lower than off-grid PV + Diesel + Batteries and around 10 times lower than off-grid PV + Diesel. Moreover, although lower $\mathrm{CO}_{2}$ emissions occur in the PV + Diesel + Batteries system, the on-grid PV-only system under net metering is better in environmental terms because it does not use batteries. The sensitivity analyses showed that the variables which most affects the NPC of the optimal PV + Diesel are the annual fuel price inflation and the interest rate. In the case of PV + Diesel + Batteries, fuel inflation did not have a great influence on NPC, though the price of PV panels and batteries did have an important influence. In the optimisation of the on-grid PV-only system under net metering with one-year rolling credit modality, the variable which most affected the NPC of the optimal system was the price of PV panels.

Acknowledgments: This work was supported by the Ministerio de Economía y Competitividad of the Spanish Government under Project ENE2013-48517-C2-1-R.

Author Contributions: Carlos J. Sarasa-Maestro and Rodolfo Dufo-López collected data, obtained and analysed the numerical results; José L. Bernal-Agustín wrote and revised the paper. All authors revised and approved the manuscript.

Conflicts of Interest: The authors declare no conflict of interest.

\section{References}

1. Badcock, J.; Lenzen, M. Subsidies for electricity-generating technologies: A review. Energy Policy 2010, 38, 5038-5047. [CrossRef]

2. Sarasa-Maestro, C.J.; Dufo-López, R.; Bernal-Agustín, J.L. Photovoltaic remuneration policies in the European Union. Energy Policy 2013, 55, 317-328. [CrossRef]

3. Cucchiella, F.; D'Adamo, I.; Rosa, P. Industrial Photovoltaic Systems: An Economic Analysis in Non-Subsidized Electricity Markets. Energies 2015, 8, 12865-12880. [CrossRef]

4. Bürer, M.J.; Wüstenhagen, R. Which renewable energy policy is a venture capitalist's best friend? Empirical evidence from a survey of international cleantech investors. Energy Policy 2009, 37, 4997-5006. [CrossRef]

5. Botero, S.; Morales, C. Análisis Del Instrumento Regulatorio "Medición Neta" (Net Metering) Y Su Potencial Aplicación Al Caso Colombiano. Rev. Energy 2008, 40, 53-66. 
6. Darghouth, N.R.; Barbose, G.; Wiser, R. The impact of rate design and net metering on the bill savings from distributed PV for residential customers in California. Energy Policy 2011, 39, 5243-5253. [CrossRef]

7. Royal Decree 661//2007, dated 25th of May by Which the Activity of Production of Electric Energy in a Special Regime is Regulated, Spain. Available online: http://www.boe.es/boe/dias/2007/05/26/ (accessed on 3 May 2016).

8. Dufo-López, R.; Bernal-Agustín, J.L. A comparative assessment of net metering and net billing policies. Study cases for Spain. Energy 2015, 84, 684-694. [CrossRef]

9. Talavera, D.L.; de La Casa, J.; Muñoz-Cerón, E.; Almonacid, G. Grid parity and self-consumption with photovoltaic systems under the present regulatory framework in Spain: The case of the University of Jaén Campus. Renew. Sustain. Energy Rev. 2014, 33, 752-771. [CrossRef]

10. Linssen, J.; Stenzel, P.; Fleer, J. Techno-economic analysis of photovoltaic battery systems and the influence of different consumer load profiles. Appl. Energy 2016. [CrossRef]

11. Beck, T.; Kondziella, H.; Huard, G.; Bruckner, T. Assessing the influence of the temporal resolution of electrical load and PV generation profiles on self-consumption and sizing of PV-battery systems. Appl. Energy 2016, 173, 331-342. [CrossRef]

12. Luthander, R.; Widén, J.; Nilsson, D.; Palm, J. Photovoltaic self-consumption in buildings: A review. Appl. Energy 2015, 142, 80-94. [CrossRef]

13. Mulder, G.; Six, D.; Claessens, B.; Broes, T.; Omar, N.; van Mierlo, J. The dimensioning of PV-battery systems depending on the incentive and selling price conditions. Appl. Energy 2013, 111, 1126-1135. [CrossRef]

14. Ren, Z.; Grozev, G.; Higgins, A. Modelling impact of PV battery systems on energy consumption and bill savings of Australian houses under alternative tariff structures. Renew. Energy 2016, 89, 317-330. [CrossRef]

15. Castillo-Cagigal, M.; Caamaño-Martín, E.; Matallanas, E.; Masa-Bote, D.; Gutiérrez, A.; Monasterio-Huelin, F.; Jiménez-Leube, J. PV self-consumption optimization with storage and Active DSM for the residential sector. Sol. Energy 2011, 85, 2338-2348. [CrossRef]

16. Widén, J. Improved photovoltaic self-consumption with appliance scheduling in 200 single-family buildings. Appl. Energy 2014, 126, 199-212. [CrossRef]

17. McKenna, E.; McManus, M.; Cooper, S.; Thomson, M. Economic and environmental impact of lead-acid batteries in grid-connected domestic PV systems. Appl. Energy 2013, 104, 239-249. [CrossRef]

18. Merei, G.; Moshövel, J.; Magnor, D.; Sauer, D.U. Optimization of self-consumption and techno-economic analysis of PV-battery systems in commercial applications. Appl. Energy 2016, 168, 171-178. [CrossRef]

19. Kästel, P.; Gilroy-Scott, B. Economics of pooling small local electricity prosumers-LCOE \& self-consumption. Renew. Sustain. Energy Rev. 2015, 51, 718-729.

20. Chiaroni, D.; Chiesa, V.; Colasanti, L.; Cucchiella, F.; D'Adamo, I.; Frattini, F. Evaluating solar energy profitability: A focus on the role of self-consumption. Energy Convers. Manag. 2014, 88, 317-331. [CrossRef]

21. Nicholls, A.; Sharma, R.; Saha, T.K. Financial and environmental analysis of rooftop photovoltaic installations with battery storage in Australia. Appl. Energy 2015, 159, 252-264. [CrossRef]

22. Lang, T.; Ammann, D.; Girod, B. Profitability in absence of subsidies: A techno-economic analysis of rooftop photovoltaic self-consumption in residential and commercial buildings. Renew. Energy 2016, 87, 77-87. [CrossRef]

23. Parra, D.; Patel, M.K. Effect of tariffs on the performance and economic benefits of PV-coupled battery systems. Appl. Energy 2016, 164, 175-187. [CrossRef]

24. Jargstorf, J.; De Jonghe, C.; Belmans, R. Assessing the reflectivity of residential grid tariffs for a user reaction through photovoltaics and battery storage. Sustain. Energy Grids Netw. 2015, 1, 85-98. [CrossRef]

25. Dufo-López, R.; Cristóbal-Monreal, I.R.; Yusta, J.M. Optimisation of PV-wind-diesel-battery stand-alone systems to minimise cost and maximise human development index and job creation. Renew. Energy 2016, 94, 280-293. [CrossRef]

26. Dufo-López, R. iHOGA (Improved Hybrid Optimization by Genetic Algorithms). Available online: http:/ / personal.unizar.es/rdufo/ (accessed on 26 February 2016).

27. Dufo-López, R.; Bernal-Agustín, J.L. Techno-economic analysis of grid-connected battery storage. Energy Convers. Manag. 2015, 91, 394-404. [CrossRef]

28. Dufo-López, R. Optimisation of size and control of grid-connected storage under real time electricity pricing conditions. Appl. Energy 2015, 140, 395-408. [CrossRef] 
29. Darghouth, N.R.; Wiser, R.H.; Barbose, G.; Mills, A.D. Net metering and market feedback loops: Exploring the impact of retail rate design on distributed PV deployment. Appl. Energy 2016, 162, 713-722. [CrossRef]

30. Darghouth, N.R.; Wiser, R.H.; Barbose, G. Customer economics of residential photovoltaic systems: Sensitivities to changes in wholesale market design and rate structures. Renew. Sustain. Energy Rev. 2016, 54, 1459-1469. [CrossRef]

31. Christoforidis, G.C.; Panapakidis, I.P.; Papadopoulos, T.A.; Papagiannis, G.K.; Koumparou, I.; Hadjipanayi, M.; Georghiou, G.E. A model for the assessment of different Net-Metering policies. Energies 2016, 9, 262. [CrossRef]

32. Branker, K.; Pathak, M.J.M.; Pearce, J.M. A review of solar photovoltaic levelized cost of electricity. Renew. Sustain. Energy Rev. 2011, 15, 4470-4482. [CrossRef]

33. Schiffer, J.; Sauer, D.U.; Bindner, H.; Cronin, T.; Lundsager, P.; Kaiser, R. Model prediction for ranking lead-acid batteries according to expected lifetime in renewable energy systems and autonomous power-supply systems. J. Power Sources 2007, 168, 66-78. [CrossRef]

34. Dufo-López, R.; Lujano-Rojas, J.M.; Bernal-Agustín, J.L. Comparison of different lead-acid battery lifetime prediction models for use in simulation of stand-alone photovoltaic systems. Appl. Energy 2014, 115, 242-253. [CrossRef]

35. Matteson, S.; Williams, E. Residual learning rates in lead-acid batteries: Effects on emerging technologies. Energy Policy 2015, 85, 71-79. [CrossRef]

36. Hoppmann, J.; Volland, J.; Schmidt, T.S.; Hoffmann, V.H. The economic viability of battery storage for residential solar photovoltaic systems-A review and a simulation model. Renew. Sustain. Energy Rev. 2014, 39, 1101-1118. [CrossRef]

37. García-Triniño, P.; Llorens-Iborra, F.; García-Pichardo, E.; García-Vázquez, C.A.; Fernández-Ramírez, L.M. Economic viability of small power photovoltaic facilities for dwellings by using the net-metering mode. DYNA 2014, 89, 229-235.

38. PVGIS, Photovoltaic Geographical Information System. Available online: http://re.jrc.ec.europa.eu/pvgis / (accessed on 18 May 2016).

39. STA, Solar Trade Association UK. Available online: http://www.solar-trade.org.uk/ (accessed on 19 May 2016).

40. Commission Regulation (EU) No 182/2013 of 1 March 2013 Making Imports of Crystalline Silicon Photovoltaic Modules and Key Components (i.e. Cells and Wafers) Originating in or Consigned from the People's Republic of China Subject to Registration. Available online: http:/ / eur-lex.europa.eu/legalcontent/EN/TXT/?uri=CELEX\%3A32013R0182 (accessed on 16 May 2016).

41. LME, London Metal Exchange. Available online: http:/ /www.lme.com/ (accessed on 15 May 2016).

42. Dufo-López, R.; Bernal-Agustín, J.L.; Yusta-Loyo, J.M.; Domínguez-Navarro, J.A.; Ramírez-Rosado, I.J.; Lujano, J.; Aso, I. Multi-objective optimization minimizing cost and life cycle emissions of stand-alone PV-wind-diesel systems with batteries storage. Appl. Energy 2011, 88, 4033-4041. [CrossRef]

43. McManus, M.C. Environmental consequences of the use of batteries in low carbon systems: The impact of battery production. Appl. Energy 2012, 93, 288-295. [CrossRef]

44. Balcombe, P.; Rigby, D.; Azapagic, A. Environmental impacts of microgeneration: Integrating solar PV, Stirling engine CHP and battery storage. Appl. Energy 2015, 139, 245-259. [CrossRef]

(C) 2016 by the authors; licensee MDPI, Basel, Switzerland. This article is an open access article distributed under the terms and conditions of the Creative Commons Attribution (CC-BY) license (http://creativecommons.org/licenses/by/4.0/). 